\title{
ANALISIS PELAKSANAAN PERKULIAHAN PENGANTAR EKONOMI BERBASIS KOMPETENSI (STUDI PADA PERGURUAN TINGGI DI KOTA PADANG)
}

\author{
Elva Dona \\ mifthah02@gmail.com
}

\begin{abstract}
Abstrak
Materi Pengantar Ekonomi yang diajarkan di semester satu Program Studi Akuntansi tidak banyak mengalami perubahan sementara perkembangan ekonomi dan isu global berjalan dengan sangat cepat Tujuan penelitian ini adalah untuk menganalisis kesiapan dan pelaksanaan perkuliahan Pengantar Ekonomi sesuai Kompetensi dan KKNI serta perkembangan isu global pada program studi rumpun Ekonomi (Akuntans, Manajemen, Perbankan) pada Universitas " $X$ " Padang dan STIE " $Y$ " Padang. Penelitian ini membahas: 1. bagaimana relevansi antara Kurikulum dalam Pengantar Ekonomi di Perguruan Tinggi dengan kebutuhan/kompetensi yang diharapkan dimiliki oleh mahasiswa ekonomi/akuntansi di perguruan tinggi di Kota Padang. 2. Menggambarkan current status cakupan pengajaran materi Pengantar Ekonomi dalam mata kuliah, kesiapan dosen ekonomi/akuntansi mengintegrasikan materi ekonomi dalam perkuliahan, dan dukungan program studi pada staf pengajarnya untuk mengintegrasikan materi ekonomi dalam matakuliah. Penelitian ini juga melihat kesiapan individu dan dukungan prodi terhadap cakupan pengajaran materi ekonomi dalam mata kuliah, serta mengeksplorasi persepsi implikasi pengadopsian isu global dalam ekonomi terhadap praktik dan pengajaran akuntansi. Penelitian survey dilakukan untuk menjawab pertanyaan penelitian.

Penelitian ini menggunakan pendekatan kualitatif dan bersifat kasus, Pengumpulan data menggunakan metode wawancara tertutup dan terbuka, observasi dan dokumentasi. Keabsahan data dengan credibility, transferability, dan dependability. Analisis data dengan tahapan data collection, reduction, display, dan conclusion.

Hasil penelitian menunjukkan bahwa Perguruan Tinggi di Padang tersebut masih dalam proses mempersiapkan kurikulum baru yang berbasis KKNI dan mengikuti isu perkembangan global dalam perekonomian. Materi Pengantar Ekonomi yang diajarkan di semester satu Program Studi Akuntansi di Perguruan Tinggi Di Kota Padang banyak mengalami perubahan mengikuti perkembangan ekonomi dan isu global. Cakupan pengajaran materi Pengantar Ekonomi sudah sesuai tuntutan kompetensi (KKNI) dalam mata kuliah, serta kesiapan dosen mengintegrasikan materi ekonomi dalam perkuliahan, dan dukungan program studi dalam memfasilitasi dosen mengajarkan materi sudah bagus.
\end{abstract}

Kata kunci : KKNI, Kompetensi, Padang, Pengantar Ekonomi, Perguruan Tinggi

\section{Pendahuluan}

Tantangan masa depan bagi bangsa meliputi tersedianya sumberdaya manusia(SDM) terdidik, terlatih dan terampil yang memiliki daya saing di tingkat global. Perguruan tinggi memiliki peran yang besar untuk menyiapkan SDM tersebut dengan 
memadukan antara berkah demografi dan penerapan kurikulum berbasis KKNI sebagai modal utama dalam membangun daya saing bangsa yang berkelanjutan.

Kurikulum merupakan komponen penting pendidikan.Kurikulum Perguruan Tinggi harus mengikuti KKNI yang harus menyiapkan SDM Indonesia dalam menghadapi MEA dan bersaing secara global (sesuai dengan tuntutan Perpres No. 08 tahun 2012 tentang Dengan adanya KKNI kompetensi seseorang tidak dilihat dari ijasahnya, tetapi dilihat dari kerangka kualifikasi yang disepakati secara nasional, sehingga pengakuan terhadap hasil pendidikan seseorang tersebut transparan dan dapat dipertanggungjawabkan. Di kalangan pendidikan tinggi, khususnya di tingkat program studi, pengelolaan pembelajaran dilakukan melalui tahapan : 1) penetapan profil kelulusan, 2) merumuskan learning outcome, 3) merumuskan kompetensi bahan kajian, 4) pemetaan learning outcome bahan kajian, 5) pengemasan mata kuliah, 6) penyusunan kerangka kurikulum, 7) penyusunan rencana perkuliahan. Hal tersebut dilakukan dalam rangka memberikan jaminan mutu luaran pendidikan tinggi. Kerangka Kualifikasi Nasional Indonesia, dan Peraturan Menteri Pendidikan dan Kebudayaan Republik Indonesia No. 73 Tahun 2013 tentang Penerapan Kerangka Kualifikasi Nasional Indonesia Bidang Pendidikan Tinggi). Kurikulum berbasis KKNI merupakan upaya melakukan kualifikasi terhadap lulusan perguruan tinggi di Indonesia. Kerangka ini menjadi acuan dalam penyusunan capaian pembelajaran lulusan dari setiap jenjang pendidikan secara nasional. Dampaknya adalah penyusunan kurikulum baru di setiap program studi, dengan segala konsekuensinya, bahwa kurikulum pada awalnya mengacu pada pencapaian kompetensi menjadi mengacu pada capaian pembelajaran (learning outcome), yang merupakan internalisasi dan akumulasi ilmu pengetahuan, ketrampilan, sikap dan kompetensi (akumulasi kemampuan seseorang dalam melaksanakan suatu deskripsi kerja secara terukur, mencakup aspek kemandirian dan tanggungjawab) yang dicapai melalui proses pendidikan yang terstruktur dan mencakup satu bidang ilmu/keahlian tertentu

Memasuki abad 21 mahasiswa perlu disiapkan ketrampilan (Hannah and Frances Hunt:2012) :

1. An ability to communicate with people from a range of social and cultural backgrounds;

2. An ability to work within teams of people from a range of backgrounds and other countries;

3. Openness to a range of voices and perspectives from around the world;

4. Willingness to resolve problems and seek solutions; 
5. Recognition and understanding of the impact of global forces on people's lives;

6. Willingness to play an active role in society at local, national and international level.

Aplikasi Teknologi Informasi (TI) di Indonesia relatif meluas, dan kompleks. Hal ini membawa implikasi positif dan negatif dalam pembelajaran ekonomi. Secara positif, aplikasi TI memberikan efektivitas, efisiensi dan eficacy dalam mendukung pencapaian tujuan pembelajaran. Mahasiswa akan terfasilitasi dalam pemecahan masalah belajar dan memiliki kesempatan dalam berkreasi dalam belajar. Sisi negatif dari aplikasi TI adalah tercurahnya waktu yang berimplikasi biaya (opportuniy cost) bagi mahasiswa bahkan dosen ekonomi dalam akses TI yang tidak relevan dengan tujuan pembelajaran.

Perguruan Tinggi, KKNI dan Daya Saing Bangsa Perguruan tinggi memiliki peran yang besar dalam perwujudan daya saing bangsa, karena perguruan tinggi merupakan pusat penggerak inovasi dan aplikasi teknologi, baik secara entrepreneuship maupun technopreneurship. Perguruan Tinggi menjadi motor penggerak inovasi dan kreativitas guna menembus persaingan, membangun kerjasama dengan berbagai industri, dan berinisiatif mondorong mahasiswa untuk melakukan usaha dan berdiri sebagai wirausaha, membangun kompetisi dan meningkatkan daya saing dengan negara-negara lain. KKNI, hadir untuk menyongsong perwujudan daya saing Indonesia dalam menghadapi tantangan masa depan di era global, diantaranya adalah : 1) Berlakunya pasar bebas (WTO, AEC, APEC, CAFTA) 2) kemajuan teknologi informasi, 3) konvergensi ilmu pengetahuan dan teknologi, 4) ekonomi berbasis pengetahuan, 5) pergeseran kekuatan ekonomi dunia, 6) mutu, relevansi, daya saing dan transformasi sector pendidikan. Oleh sebab itu, dengan KKNI menunjukkan adanya standart secara nasional, yang dapat diikuti oleh setiap penyelenggara pendidikan, sehingga kompetensinya tetap terjaga untuk menembus daya saing bangsa.

Lulusan Pendidikan tinggi perlu dibekali dengan kemampuan yang bisa digunakan untuk membangun daya saing, diantaranya adalah pengetahuan dan ketrampilan profesional yang kompetitif, baik dalam bidang ilmu pengetahuan dan teknologi, kemampuan berbahasa asing, teknologi informasi, penguatan karakter maupun kemampuan global, sehingga lulusan pendidikan tinggi mampu untuk bersaing di tingkat nasional. Dalam kaitannya dengan lulusan Ekonomi (Akuntasi, Manajemen, Perbankan, Administrasi Niaga dan lain-lain) perlu membekali dengan ketrampilan alternative 
diantaranya : peneliti, ajun akuntan, pengembang pendidikan, dan sebagainya yang memiliki kemampuan berpikir kreatif, inovatif.

Mata kuliah Pengantar Ilmu Ekonomi ada dalam kurikulum rumpun ekonomi ( Akuntansi , Manajemen, Administrasi Niaga, Perbankan dan lain-lain) yang diajarkan pada semester permulaan (satu atau dua). Mata kuliah ini mengajarkan pengetahuan dasar mengenai konsep dasar ekonomi dalam lingkup mikro dan makro. Pemahaman mahasiswa terhadap bahasan tersebut menjadi dasar untuk memahami matakuliah selanjutnya sesuai dengan jurusan yang mereka ambil baik akuntansi, manajemen, perbankan atau yang lainnya selanjutnya akan sangat membantu mahasiswa ketika mengkaji kondisi perekonomian yang berlangsung dan membantu mahasiswa ketika terjun ke dunia kerja. Tantangan dan peran strategis dosen pengampu sebagai agen pembelajaran adalah pembaharuan dan inovasi pembelajaran dalam mendukung mahasiswa mencapai tujuan pendidikan tinggi. Kompetisi MEA membawa implikasi peningkatan kompetensi mahasiswa dengan perangkat pengetahuan, nilai-nilai kehidupan dan keterampilan yang relevan. Dinamika aplikasi teknologi informasi di masyarakat perlu direvitalisasikan dalam pembelajaran ekonomi yang semakin efektif dan efisien. Mahasiswa pembelajaran ekonomi memiliki potensi dalam memanfaatkan sumber daya dalam persaingan global termasuk era MEA.

\section{Tinjauan Pustaka}

Indonesia merupakan negara dengan jumlah penduduk paling banyak di kawasan Asia Tenggara. Jumlah penduduk yang besar yang pada tahun 2015 diproyeksikan mencapai 255,5 juta jiwa atau sebesar 40,3\% dari jumlah penduduk di seluruh wilayah ASEAN (Armida , 2014). Diperkirakan 38 dari 100 penduduk usia produktif di negaranegara ASEAN adalah penduduk Indonesia. Artinya Indonesia mempunyai potensi untuk menjadi pemasok tenaga kerja terbesar di ASEAN terutama di negara-negara yang proporsi usia produktifnya kecil, misalnya Singapura dan Thailand. Kondisi ini akan bertahan untuk beberapa puluh tahun ke depan. Pertumbuhan penduduk Indonesia yang terus meningkat mengakibatkan jumlah angkatan kerja juga terus meningkat setiap tahunnya di tengah kesempatan kerja yang terbatas karena pertumbuhan ekonomi belum mampu menyerap angkatan kerja tersebut masuk ke dalam pasar kerja.

Jauh sebelum pendidikan nasional tertata, hubungan antar bangsa telah berlangsung dalam kegiatan perdagangan, misi agama, komunitas sosial budaya dan aktivitas yang lainnya. Hubungan antar bangsa ini secara dinamik berpengaruh dalam pengelolaan sistem 
pendidikan dan sekolah di Indonesia. Terbukti berbagai pemikiran tentang filosofis, teknisteknis pedagogik dan perkembangan Teknologi informasi bangsa lain menjadi referensi, acuan, dan fasilitas dalam tata kelola pendidikan di Indonesia.

Pembelajaran di perguruan tinggi menuntut mahasiswa untuk aktif dan dosen hanya berperan sebagai fasilitator. Setiap interaksi belajar mengajar pasti bertujuan. Tujuan ini menentukan bentuk dan corak interaksi. Dalam mengajar terjadi suatu proses menguji strategi, menguji rencana yang memungkinkan timbulnya perbuatan belajar pada mahasiswa. Dosen menyusun perencanaan pembelajaran, selanjutnya memimpin dalam proses pengajaran, memotivasi dalam belajar dan selanjutnya mengawasi atau mengevaluasi hasil belajar. Upaya yang dilakukan untuk memberdayakan dosen dalam meningkatkan kualitas pembelajaran adalah dengan penyediaan kurikulum dan penjadwalan pelajaran. Oleh karena itu, diperlukan perubahan keyakinan dan sikap tentang berbagai kemungkinan dalam pembelajaran. Dosen tidak lagi sebagai pusat pembelajaran tetapi hanya sebagai fasilitator. Mahasiswa dalam proses pembelajaran dengan metode ini diharapkan mampu untuk memikirkan dan menemukan solusi ataupun ide lain terhadap suatu topik atau suatu konsep kemudian bisa dengan mahasiswa lain mendiskusikan konsep tersebut. Adanya kegiatan berpikir bersama memberi banyak keuntungan. Mahasiswa secara individual dapat mengembangkan pemikirannya masing-masing karena adanya waktu berpikir (think time) sehingga kualitas jawaban siswa juga dapat meningkat. Akuntabilitas dari pemahaman akan suatu konsep pengantar ilmu ekonomi yang dibahas akan berkembang karena setiap mahasiswa harus saling melaporkan hasil pemikiran masing-masing dan berbagi dengan seluruh kelas. Jumlah anggota kelompok kecil mendorong setiap anggota untuk terlibat secara aktif, sehingga mahasiswa yang jarang atau bahkan tidak pernah bicara di depan kelas paling tidak memberi ide atau jawaban kepada pasangannya. Keuntungan lainnya adalah pemahaman mahasiswa akan materi suatu pokok bahasan akan lebih mendalam.

Kalangan Perguruan Tinggi harus memiliki wawasan global secara umum dan wawasan ASEAN secara khusus.Untuk itu diperlukan sebuah kompetensi tambahan, yaitu kompetensi global. Kompetensi global yang mengacu pada perolehan pengetahuan yang mendalam dan pemahaman tentang isu-isu internasional, apresiasi (penghargaan) dan kemampuan untuk belajar dan bekerja dengan orang-orang dari berbagai latar belakang bahasa dan budaya, kemahiran dalam bahasa asing, dan keterampilan berfungsi secara produktif di dunia dimana masyarakat saling tergantung Dennis Van Roekel (2010) Kompetensi global memiliki 4 (empat) elemen dasar, yaitu: 1. International awareness 
(Kesadaran Internasional). 2. Appreciation of cultural diversity (Apresiasi keragaman budaya). 3. Proficiency in foreign languages (Menguasai bahasa asing). 4. Competitive skills (Keahlian Bersaing).

Memasuki perubahan dunia, Darling and Hammond (2005:11), visi pengembangan profesional bagi guru meliputi : knowledge of learners and their development in social contexts (learning; human development; language); knowledge of subject matter and curriculum goals (educational goals and purposes for skills, content, subject matter) and Knowledge of teaching (content plus content pedagogy, teaching diverse learners, assesment; classroom management). Dengan pemikiran ini dalam era perubahan pengembangan guru akan menyangkut pengajaran (teaching) dn pembelajaran (learning). Transaksional pendidik dan peserta didik tersusun sejak perencanaan, PBM, evaluasi dan tindak lanjut. Sejalan dengan pemikiran di atas, Hattie (2012:34), merekomendasikan agar Sekolah secara profesional mendukung upaya pengembangan guru dalam kegiatan berikut. - Solving instructional problem - Interpreting events in progress - Being sensitive to context - Monitoring learning - Testing hypotheses - Demonstrating respect for all in the school - Showing passion for teachingand learning - Helping students to understand complexity

Sebagai agen pembelajaran (learning agent), dosen berperan sebagai fasilitator, motivator, pemacu, perekayasa pembelajaran, dan pemberi inspirasi belajar bagi mahasiswa (peserta didik) yang berimplikasi dosen ekonomi untuk melakukan pembaharauan (up dating) informasi menyangkut konten pembelajaran dan inovasi pembelajaran yang efisien, efektif dan eficacy. Kehadiran dosen di ruang kelas dan forum pembelajaran lainnya akan memenuhi kebutuhan mahasiswa baik informasi, pemecahan masalah, pengambilan keputusan dan pengembangan dirinya. Perubahan lingkungan (eksternal) tidak pernah bisa dikendalikan baik jumlah, variasi dan mutunya. Esensi scarcities konsep dasar Ilmu Ekonomi menjadi pilihan (choice) yang kreatif dalam pemenuhan kebutuhan. Dosen ekonomi ditantang membangun diri sebagai tenaga profesional, pengembangan konten pembelajaran ekonomi global, penerapan teknologi informasi pembela.

Dalam teori produksi secara sederhana produksi adalah fungsi dari tenaga kerja dan kapital atau Q : f ( K, L). Dimana Q : produksi, K : Kapital / modal dan L : Labour / Tenaga kerja. Sebagaimana dijabarkan teori produksi 'Cobb-Douglas' yang menjadi dasar teori pertumbuhan model Swan dan Solow. Dosen ekonomi akan meluluskan subyek 
belajar yang memiliki keahlian menetapkan pilihan terbaik dari scarcities yang dihadapi. Output lulusan ini tercapai dengan standar KKNI

\section{Metode Penelitian}

Subyek dari penelitian ini adalah mahasiswa Akuntansi, Manajemen dan Perbankan semester 1 yang mengambil mata kuliah pengantar Ekonomi. Metode penelitian yang digunakan dalam penelitian ini survey kelas. Metode ini digunakan untuk memecahkan suatu masalah sebenarnya dengan melihat kekurangan dan kelebihan serta melakukan perubahan yang berfungsi sebagai peningkatan.

Upaya perbaikan ini dilakukan dengan melaksanakan tindakan untuk mencari jawaban atas permasalahan yang diangkat dari kegiatan sehari-hari di kelas. Penelitian ini merupakan upaya kolaboratif antara dosen dan mahasiswa, suatu kerjasama dengan perspektif berbeda. Penelitian ini juga merupakan kerjasama kolaboratif antara tim peneliti, yaitu dosen mata kuliah pengantar ilmu ekonomi yang masing-masing memegang suatu peran dalam pelaksanaan penelitian dari tahap awal sampai akhir.

Metode pengumpulan data dengan cara observasi, tes, dokumentasi. Penelitian survey dilakukan untuk menjawab pertanyaan penelitian. Penelitian ini menggunakan pendekatan kualitatif dan bersifat kasus, Pengumpulan data menggunakan metode wawancara tertutup dan terbuka, observasi dan dokumentasi. Keabsahan data dengan credibility, transferability, dan dependability. Analisis data dengan tahapan data collection, reduction, display, dan conclusion.

Penelitian ini membahas: 1. bagaimana relevansi antara Kurikulum dalam Pengantar Ekonomi di Perguruan Tinggi dengan kebutuhan/kompetensi yang diharapkan dimiliki oleh mahasiswa ekonomi/akuntansi di perguruan tinggi di Kota Padang. 2. Menggambarkan current status cakupan pengajaran materi Pengantar Ekonomi dalam mata kuliah, kesiapan dosen ekonomi/akuntansi mengintegrasikan materi ekonomi dalam perkuliahan, dan dukungan program studi pada staf pengajarnya untuk mengintegrasikan materi ekonomi dalam matakuliah. Penelitian ini juga melihat kesiapan individu dan dukungan prodi terhadap cakupan pengajaran materi ekonomi dalam mata kuliah, serta mengeksplorasi persepsi implikasi pengadopsian isu global dalam ekonomi terhadap praktik dan pengajaran akuntansi. 


\section{Hasil dan Pembahasan}

Program Studi Pendidikan Ekonomi (PE) perlu merespon dengan program-program yang relevan dengan kebutuhan SDM memasuki masyarakat yang semakin langsung (inherent) dalam kehidupan kita (Ismanto:2014). MEA 2015 merupakan konvensi yang telah disepakatai Pemerintah Indonesia untuk ditindak lanjuti bagi kesejahteraan bangsa Indonesia. Menurut UU 12 tahun 2012, Interaksi sosial dilakukan dalam pembelajaran, pencarian kebenaran ilmiah, penguasaan dan/atau pengembangan Ilmu Pengetahuan dan Teknologi serta pengembangan Perguruan Tinggi sebagai lembaga ilmiah. Peserta didik pembelajaran ekonomi memiliki potensi dalam memanfaatkan sumber daya dalam persaingan global termasuk era MEA. Era persaingan memerlukan kompetensi yang relevan dengan tantangan yang akan dihadapinya.

Studi ini bertujuan untuk menganalisis pembelaran ekonomi yang mengakomodasi kebutuhan industry. Berdasarkan analisis isi terhadap kurikulum mencoba menemukan perbedaan sistem pembelajaran dan kurikulum yang beragam berdampak pada perbedaan kompetensi yang dihasilkan. Penelitian ini bertujuan menggambarkan current status cakupan pengajaran materi ekonomi dalam mata kuliah, kesiapan dosen mengintegrasikan materi ekonomi dalam konteks globalisasi dalam perkuliahan dan dukungan program studi pada staf pengajarnya untuk mengintegrasikan materi ekonomi dalam mata kuliah. Penelitian ini juga menguji pengaruh kesiapan individu dan dukungan prodi terhadap cakupan pengajaran materi ekonomi dalam mata kuliah. Penelitian survey dilakukan untuk menjawab pertanyaan penelitian. Hasil survey pada dosen ekonomi dari perguruan tinggi di kota Padang.

Hasil Survey menunjukkan bahwa cakupan pengajaran materi ekonomi dalam mata kuliah, kesiapan dosen ekonomi mengintegrasikan materi ekonomi dalam perkuliahan, dan dukungan program studi dalam memfasilitasi dosen mengajarkan materi ekonomi masih relatif rendah. Penelitian ini juga menemukan bahwa kesiapan individu berpengaruh signifikan terhadap cakupan pengajaran materi ekonomi, sedangkan dukungan institusi ditemukan tidak signifikan. Hasil survey mengenai persepsi implikasi pengadopsian materi globalisasi terhadap praktik \& pengajaran ekonomi menunjukkan bahwa dosen menganggap perlu perubahan kurikulum, dan menganggap materi tentang perekonomian global merupakan materi yang penting untuk dimasukkan dalam kurikulum dengan cakupan yang lebih luas.

Aplikasi Teknologi Informasi (TI) di Indonesia relatif meluas, dan kompleks. Hal ini membawa implikasi positif dan negatif dalam pembelajaran ekonomi. Secara positif, 
aplikasi TI memberikan efektivitas, efisiensi dan eficacy dalam mendukung pencapaian tujuan pembelajaran. Peserta didik akan terfasilitasi dalam pemecahan masalah belajar dan memiliki kesempatan dalam berkreasi dalam belajar. Sisi negatif dari aplikasi TI adalah tercurahnya waktu yang berimplikasi biaya (opportuniy cost) bagi siswa bahkan guru ekonomi dalam akses TI yang tidak relevan dengan tujuan pembelajaran.

Pemberdayaan dosen diselenggarakan melalui pengembangan diri yang dilakukan secara demokratis, berkeadilan, tidak diskriminatif, dan berkelanjutan dengan menjunjung tinggi hak asasi manusia, nilai keagamaan, nilai kultural, kemajemukan bangsa, dan kode etik profesi . Hal ini menjadi tantangan bagi dosen ekonomi sebagai agen pembelajaran akan melakukan pembaharuan konten (kompetensi profesional), inovasi pembelajaran (kompetensi pedagogik), ketrampilan komunikasi (kompetensi sosial) dan kemartaban diri (kompetensi pribadi).

Pertanggungjawaban profesi, perubahan lingkungan (globalisasi - MEA); teknologi informasi, dan akses organisasi profesi menjadi tantangan guru ekonomi. Dosen ekonomi meluluskan insan yang berpengetahuan, terampil dan menguasai nilai-nilai dalam penetapan pilihan pemecahan scarcities secara eficien, efektif dan eficacy.

Implikasinya adalah Mata kuliah Pengantar Ekonomi dalam penetapan learning outcomes, learning process, improvement and performance. Namun kenyataan di lapangan menunjukkan antusias mahasiswa dalam mengikuti mata kuliah ini masih rendah. Berdasarkan pengamatan di lapangan, mahasiswa pada saat perkuliahan berlangsung banyak yang kurang memperhatikan penjelasan dari dosen, mengobrol, kurang aktif dalam bertanya atau menjawab pertanyaan karena malu, gengsi (takut dianggap tidak pintar), sungkan kepada dosen dan karena metode pembelajarannya kurang sesuai. Akibatnya jika disuruh menjawab pertanyaan secara langsung banyak yang tidak bisa karena pemahaman mereka terhadap konsep pengantar ilmu ekonomi masih rendah. Rendahnya pemahaman mahasiswa terhadap konsep pengantar ilmu ekonomi juga dapat dilihat dari prestasi belajarnya yang tidak optimal.

Untuk mengatasi masalah di atas, diperlukan inovasi dengan mengimplementasikan metode pembelajaran kooperatif dan atau kolaboratif guna meningkatkan pemahaman mahasiswa terhadap konsep dasar pengantar ilmu ekonomi. Indikator keberhasilan keberhasilan dari tindakan yang dilakukan dapat dilihat dari 1. Pemahaman mahasiswa terhadap konsep dasar pengantar ilmu ekonomi meningkat. 2.Antusiasme mahasiswa dalam belajar mata kuliah pengantar ilmu ekonomi. 3. Hasil belajar mahasiswa. 4. Keterampilan dosen dalam mengembangkan metode pembelajaran. 


\section{Kesimpulan dan Saran}

Materi Pengantar Ekonomi yang diajarkan di semester satu telah mengalami banyak perubahan terkait perkembangan ekonomi dan isu global. Hasil penelitian menunjukkan bahwa Perguruan Tinggi di Padang tersebut masih dalam proses mempersiapkan kurikulum baru yang berbasis KKNI dan mengikuti isu perkembangan global dalam perekonomian. Materi Pengantar Ekonomi banyak mengalami perubahan Cakupan pengajaran materi Pengantar Ekonomi sudah sesuai tuntutan kompetensi (KKNI) dalam mata kuliah, serta kesiapan dosen mengintegrasikan materi ekonomi dalam perkuliahan, dan dukungan program studi dalam memfasilitasi dosen mengajarkan materi sudah bagus.

\section{Daftar Pustaka}

Belferick Manulang. 2013. Grand Desain Pendidikan Karakter Generasi Emas 2045. Jurnal Pendidikan Karakter Tahun III. Nomor 1, Februari. 2013

Darling, Linda and Hammond John Branssford (editor), 2005, Preparing Teacher for A Changing World, What Teachers Should Learn and Be Able to Do, Jossey-Bass, USA

Departemen Perdagangan Republik Indonesia, Menuju Asean Economic Community, Departemen Perdagangan, Jakarta

Hannah McGough and Frances Hunt, 2012, The Global Dimension: A Practical Handbook for Teacher Educators, Development Education Research Centre, www.ioe.ac.uk/derc Hattie, John, 2012, Visible Learning for Teachers, Maximizing Impact on Learning, Routledge 2 Park Square, Milton Park, Abingdon,Oxon. New York

Ismanto, Bambang, 2014, Arsitektur Kurikulum Pendidikan Ekonomi Memasuki Masyarakat Ekonomi Asia, Disajikan dalam 'Call Paper' Seminar Aspropendo, UNS, Surakarta , 17 18 Oktober 2014

Peraturan Menteri Pendidikan dan Kebudayaan, Nomer : Tahun 2015, tentang Rencana Strategis Kementeriaan Pendidikan dan Kebudayaan Tahun 2015-2019. Peraturan Presiden Nomer : 2 Tahun 2015, tentang Rencana Pembangunan Jangka Menengah Nasional, Tahun 2015-2019 Undang-Undang Nomer : 14 Tahun 2005, tentang Guru dan Dosen UndangUndang Nomer : 20 Tahun 2003, tentang Sistem Pendidikan Nasional 